\title{
Waiters' craft-related actions studied from the perspective of time-geography
}

\author{
Lars Eriksson, Inger M. Jonsson \& Åsa Öström \\ School of Hospitality, Culinary Arts and Meal Science, \\ Örebro University, Sweden (lars.g.eriksson@oru.se)
}

\begin{abstract}
The aim of this paper is to visualize, communicate and understand the vocational knowledge of a waiter's craft, including how to perform table-setting and serving. The underlying theoretical perspectives are Culinary Arts and Meal Science, Craft Science, and Time-Geography. Basic time-geographical concepts used in the study are project, $\log$, notation and constraint. The empirical data consist of two postulated serving methods wherein different procedures are identified. The data are based on the first author's vocational experience and are described by logs of procedures. Questions in the logs concerning capacity, coupling, or authority constraints indicate limits to what is possible. Additionally, one of the serving methods is shown by a notation, displaying the waiter's and the guests' actions in relation to the procedures. The notation, complemented with a drawing of the room, provides knowledge about when, where, and for how long a serving procedure lasts. Through the use of time-geographical tools, the waiter's craft procedures can be described and interpreted. Thus, it became possible to visualize, communicate, and acquire a deeper understanding of how the waiter in her vocational craft predicts and masters how time and materiality together with spatiality affect a meal event.
\end{abstract}

Keywords: time-geography, vocational knowledge, waiter, restaurant craft, tablesetting, serving 


\section{Introduction}

In the field of craft, attention is often directed to the result and assessments are made of the finished product or service. A craftsperson's vocational role often involves many different assessments being made during the performance of a craft procedure. The assessments are often implicit knowledge and are undertaken silently. In a vocational internship, it is less important to be able to give explanations of what the assessments are; it is more important that they are the right ones for the craft procedure (Almevik, 2011). However, in order to create the conditions for knowledge transfer in vocational education and training, it is necessary to achieve a profound depth and to change the focus from performing to examining how to perform (Sjömar, 2017). In this article, the aim is to increase the current understanding of the waiter's vocational knowledge by using timegeographical approaches and methods.

In general, perceptions of a waiter's work and skill vary. In some contexts, serving and table-setting are considered to be a simple type of work with a few requisites. Work as a waiter is often the first job of young people, who can begin the role as novices since education is rarely in demand (Statens offentliga utredningar [SOU], 2017). In other contexts, however, table-setting and serving are considered to be stature-enhancing and prestigious forms of work. For example, the daily press in Sweden reports on the professional table-setting at the Nobel Prize dinner. The textual descriptions, which are often illustrated by accompanying pictures, reflect how the serving procedures are implemented. With the Nobel Prize dinner as an example, the practical performance of the waiter's procedures for table-setting and serving requires knowledge of which utensils will be presented, where on the table they will be placed, and when the serving will be done. Serving also requires activities that occur in short sequences, often with minimum time and full attention necessarily directed to guests. All these are activities with specific time-space requirements. A skilled and experienced waiter repeats serving activities several times until they become routines, stays one-step ahead, and has the ability to predict the next event. Once such actions become routines, even a skilled waiter will have difficulty in communicating a thorough description of what occurs in a serving situation. Almevik (2014) points out the importance, for dissemination of knowledge, of linking theory and practice together rather than separating them. One way to go about this, means Almevik (2017), is for crafts-persons to learn both to document and communicate their own knowledge.

The philosopher Polanyi (1958) wrote that when an action is not reflected upon, and when its performance is not assessed, we lose the description of how that craft is executed. Polanyi states that when attention is not paid to the individual parts of a procedure, it becomes impossible to identify them. On the other hand, Ingold (2013) believes that it is the gravest of errors to regard such know- 
how as a subconscious act, or as something that practitioners can do without thinking, since the work involves the most intense concentration.

The time-geographical approach provides conceptual tools which are useful for investigating processes of the physical connection between material in space over time. Ellegård (2019) underlines that time-geography helps in the analysing of how different needs are satisfied differently depending on where, when, and by whom the activities are performed. Hägerstrand (1970) believes that time and space are inseparable, and that time is necessary to enable people and things to be brought together. This way of reasoning can be transferred to different restaurant crafts, where a variety of meal situations are dependent on their specific location in space and time. In the same way, Gustafsson (2004) suggests that no meal is carried out without the presence of different eating situations, places and rooms for dining in.

\section{Craft knowing}

A common way to describe craftsmanship involves mystifying the craft knowledge by saying that it is present 'in the body' (Sjömar, 2011). Craftsmanship is often linked to physical labor and to the fact that knowledge rests 'in the hands' or 'sits in the spine' (Almevik, 2011; Sjömar, 2011). A craft performance could be described as a procedure that involves a series of difficult decisions made (Tempte, 1982) and their risk taking is central to the performance (Pye, 1968). Schön (1983) states that practical knowledge is both problem solving and assessments of the results. In the same way, Molander (1996) suggests that discernment and attention are adjacent. Pye (1968) distinguishes craftsmanship through the concept of 'workmanship of risk' as being characterised by unprecedented work, in which the quality of a piece of work can be risked, while 'workmanship of certainty' is performed on a secure basis with a predetermined result. Attention could be seen as a key concept in practical knowledge development. A skilled practitioner is attentive to her actions and possesses an overview of the situation (Molander, 1996). We mean to say that, in line with Sjömar (2017), craft science research is both theoretical and practical; theoretical in the sense that the purpose is to gain explanations and understanding of craft procedures, and practical because the investigative methodology is included to perform the procedures.

\section{Restaurant craft}

Restaurant craft is seldom discussed and analysed through materiality. Gustafsson (2004) explains that although the dining room is important for the guest experience, even the table-setting may qualify as 'a small room' in itself. Bitner (1992) uses the term 'service-scape' for the built environment, referring to the environment where the customers interact. The creative part of the meal experience 
will occur on the laid-out table (Gustafsson, 2004). Walter (2011) uses the concept of 'experience room' and points out in her thesis that customers and employees are part of the physical environment. The craft that is performed by the waiter has to do with the waiter's ability to read the guests' expectations and needs throughout the meal (Gustafsson, 2004; Gustafsson, Öström, Johansson \& Mossberg, 2006). A server should have knowledge about the eating situation and should try to satisfy the guests' needs in the best possible way (Gustafsson, 2004; Gustafsson et al., 2006).

An invented craft procedure is often carried out by an expert with ease and in a flow. Serving food is no exception. A serving procedure will often follow the same method every day. However, the logic of how such a flow continues can be difficult for an outsider to understand without any knowledge of serving. An expert knows how to do the work. Dreyfus and Dreyfus (1988) point out that an expert uses his/her entire knowledge, including both explicit and implicit knowledge. At any rate, it is not certain that an expert who can manage a meal situation involving hundreds of people will be able to convey her knowledge. Lauvås, Handal and Nilsson (2015) propose the use of the phrase 'insight into knowledge', which refers to knowledge that we are so close to that we are hardly aware that we have it.

One step toward understanding a vocational skill is to identify and describe what is happening in each section of a procedure. Rolf (2017) classifies knowledge development into five steps. From the first step, capacities refer to actions such as taking in oxygen, i.e. breathing, further to abilities, practical skills, know-how, and, to the highest level, professional competence, which refers to professional proficiency and ability to transform knowledge processes and improve rules. Also, Dreyfus and Dreyfus (1988) also describe knowledge development in five steps, where a novice is characterised as one whose perspective is governed by rules and guidelines, further to advanced beginner, competent, skilled, and expert. An expert does not rely on rules and guidelines but regards the situation as a whole and perceives it intuitively. The similarities in the models of Rolf and Dreyfus and Dreyfus are that both present a transition from a position of dependence on others' assessments to a position of self-control.

From 1960 to 1980, craft-oriented procedures such as carving birds, filleting fish, and flaming desserts disappeared from first-class restaurants and the waiter's craftsmanship was rationalised and the tasks were reduced to carrying plates (Lundqvist, 2006). This simplification can be seen as a regression to an earlier stage of Rolf's classification system; the waiters are limited to an ability to transport. However, Billing and Wahlström (2004) state that the craftsmanship of a sommelier nowadays has been further developed. Here, the knowledge required for a sommelier can be seen as an instrument in the battle for a position within the restaurant environment (Jonsson, Nygren \& Pipping Ekström, 2006). 
One way to systematise the waiter's work is to make a mise-en-place, which means putting together the utensils for an upcoming work moment (Culinary Institute of America [CIA], 2001). A mise-an-place can be seen as a restaurant craft which can be checked against instructions. The concept of mise-an-place can be compared to the concept of 'knowing that', which is explained by Ryle (1949), who refers to a knowledge manifested through representations (i.e., the advice the headwaiter and restaurateur Uno Hedman (1999) gives that a plate should be placed two $\mathrm{cm}$ from the edge of the table). Education documents for serving and table-setting will give guidance that explains which utensils must be used depending on the menu (CIA, 2001; Hedman, 1999). The concept of 'knowing how' (Ryle, 1949), the craft procedures are executed is seldom articulated within the arena of restaurant craftmanship. Guideline descriptions seldom problematise how utensils, table-settings, and serving procedures affect the result of the waiter's work and the practical elements of eating. Schön (1983) considers that thinking and practicing are not separated; rather they form a unit: we reflect in the action. Ryle (1949) considers that the reflective practitioner is constantly in a learning situation, and a skilled practitioner is reflective. Later, Molander (1996) discussed the practitioner doing the right thing at the right time. Knowing and action are part of a waiter's everyday life. The knowledge involved in creating a meal described in the Five Aspects Meal Model (the FAMM-model) involves different parts; the room, the meeting, the products, the atmosphere, and the control system (Gustafsson et al., 2006). These parts form a whole that will hopefully please the guests. However, research has shown that what makes a meal experience a particularly good one is the social interaction between the actors (Walter, 2011). The guests' experience of a meal will include the restaurant scene, the restaurant atmosphere, and the quality of the staff, etc., all of which will be seen as the most important points (Gustafsson et al., 2006).

In this study, we will investigate how a professional practice of serving can be achieved, understood, and illustrated, through words and pictures, and also how the simple actions of supervision are built around complex systems. We will also point out how craft not only sits in the hands but is also found in reflected craft procedures.

\section{Aim}

The aim of this article is to visualize, communicate and understand the vocational knowledge of a waiter's craft, including the actions of table-setting and serving of food, based on concepts and methodology from the time-geographic approach. 


\section{Methodology}

We define the practical work of table-setting and serving as a craft and use craft science (Sjömar, 2017) as a perspective within the discipline of Culinary Arts and Meal Science (Gustafsson, 2004). 'The main character of craft science is that it is theoretical, with the aim to reach explanations and understandings, and practi$\mathrm{cal}$, as it is both to the exploratory methodology and to the research results means to be able to perform the craft procedures and control the processes' (Sjömar, 2017, p. 101-102). The first author of this article has 30 years of experience as a waiter, a headwaiter, and a designer of meals. The vocational knowledge has consisted of designing and executing meals for the private business sector in Sweden (i.e., SEB, The Nobel Foundation, The Sweden Fashion Council), and for official authorities (i.e. City of Stockholm, Swedish-arranged EU-dinners). Here, this author used his own experience as the empirical data. A person with such long and experienced vocational knowledge could be defined as a reflective practitioner (Schön, 1983), and as an expert (Dreyfus \& Dreyfus, 1988). Westerlund (2017), with a background as a gardener, and Wellton (2017), a former chef, demonstrated in their respective theses that their own practical experiences made it possible to interpret their activities and understand the practitioners' skills and knowledge. Their own experience enabled them to delve deeper into interviews with other professionals. On the other hand, when a researcher had an insider perspective, it was important for the researcher to reflect on the fact that certain questions may never be asked, as the material is too familiar (Alvesson \& Sköldberg, 2008; Wellton, 2017; Westerlund, 2017).

\section{Perspective of time-geography}

Time-geography offers opportunities to describe and analyse processes in both time and space (Lenntorp, 2011), two dimensions that are basic for all existence, as everything takes time and occupies space (Ellegård, 2019; Hägerstrand, 2009). The meaning of time-geography is 'to rise up from the flat map with its static patterns and think in terms of a world on the move' (Hägerstrand, 1982, p. 651). Time-geography has been proven useful for enhancing complex crafts that span over time and space (Hägerstrand, 1982; Jarefjäll, 2016). On an overall level timegeography has been used to investigate crafts that are carried out in various occupations and spaces (Eriksson, Seiler, Jarefjäll \& Almevik, 2019). In this study we have placed the waiter's equipment and his/her craft knowledge under the light of the concepts from time-geography.

Within time-geography a project is defined as a goal-oriented activity (Ellegård, 2019; Hägerstrand, 1982; Åquist, 1992). We define serving guests' food as a time-geographical project. In this study, the project is performed in two different ways: by plate serving and by silver service. A project will be managed by a diversity of activities, for example table-setting and serving. An activity depends 
on its individuals. Within time-geography an individual can be a human, a nonhuman (a thing), or an animal - anything that can be regarded as indivisible at the level of the investigation. In this study, individuals are, for example, a waiter and a utensil. Activities are performed at different stations. A station could be a table. Activities and individuals can be noted as trajectories in a notation, thereby it is be possible to visualize what activity is performed, when, for how long, and where (Ellegård, 2019). The notation illustrates when procedures occur simultaneously, which means beside-each-otherness, and when procedures occur in a timely manner, which means after-each-otherness. The concept of bundle refers to the grouping of several individuals and describes the staying together of two or more individuals (Ellegård, 2019). In the notation, time is regarded as a continuous dimension and the now is described by a line, the now-line, which constantly moves along the time axis, transforming future to past. It can be formulated in the words of Hägerstrand (1982, p. 651): 'a world on the move.' The continuous time dimension shall be read, in the notation, from the bottom up (Ellegård, 2019).

Empirical data in time-geography is often based on time-diaries, called logs. A $\log$ can either be factual or postulated. A factual $\log$ is a result of different requirements, obstacles, and opportunities (Hägerstrand, 1982; Mårtensson, 1979; Åquist, 1992). A postulated log reveals to what can be done in a time-space. By using a postulated log, opportunities are opened to analyse the limits of what is possible. And in the same way the problems of interpreting factual logs are avoided (Hägerstrand 1982; Mårtensson 1979; Åquist,1992). An analytical concept of time-geography is the focus on constraints. The constraints are divided into three groups: capacity, coupling, and authority, which will generate questions about what is or is not possible to manage, in a project (Hägerstrand, 1970). Capacity constraints concern the individual's opportunities related to her bodily functions and to the resources that are available to her. Coupling constraints arise from requirements for coordination between individual's, but also between individuals, tools, and material. Authority constraints concern power relations, for example, about control over the room and possibilities for access to different parts of the room (Ellegård, 2019; Åquist, 1982). Time-geography is characterised by physical realism, which means that intentions, feelings, or quality aspects of an activity are not included (Åquist, 1992). This approach is in line with our study, where we consider the work of waiter's to be dependent on the materiality. We do not intend to study the quality of the procedures.

\section{The use of the time-geographical concept - project}

The chosen project for this study involved two different ways of serving food: plate serving and silver service. In order to study the project, both the procedures of table-setting and serving have been conducted as experimental data. Based on his long vocational experience as a waiter, the first author thought through 
different serving methods and wrote down various possible scenarios. Plate serving refers to a plate with a completed portion of food being transported and served to the guest at the table. Silver service involves condiments being transported to the table in serving bowls for the guests to take from. The main food, placed on a dish, is transported to the table where the waiter offers the dish to the guest, who lifts the main food and places it onto her own plate. Based on the first author's vocational experience we have defined different dining procedures as such: table-setting; transporting of food; serving of food; and the completion of the serving procedures, (see Table 1). Since the purpose was to test the possibilities of a time-geographical approach as a method, we have chosen to limit the material by omitting the serving of drinks. What was discovered in the study was that the serving of food, without drink, provided a large amount of data which was considered sufficient to test the model's usefulness.

Table 1. Defined dining procedures.

\begin{tabular}{|c|c|c|c|}
\hline $\mathrm{Nr}$ & Procedures & Plate service & Silver service \\
\hline 1 & $\begin{array}{l}\text { Table } \\
\text { setting }\end{array}$ & $\begin{array}{l}\text { A knife and fork are } \\
\text { placed on a table, the } \\
\text { cutlery is placed at the } \\
\text { place where the guest } \\
\text { will sit. }\end{array}$ & $\begin{array}{l}\text { A knife, fork and an empty plate are placed on a table. } \\
\text { The cutlery and the plate are placed at the place } \\
\text { where the guest will sit. }\end{array}$ \\
\hline 2 & Transport & $\begin{array}{l}\text { The waiter transports } \\
\text { one plate with fish, pota- } \\
\text { toes, and sauce from the } \\
\text { kitchen into the dining } \\
\text { room and to the table. }\end{array}$ & $\begin{array}{l}\text { The waiter transports the fish dish, the sauce bowl, } \\
\text { and the bowl of potatoes from the kitchen by means of } \\
\text { a serving station. At the serving station, the serving } \\
\text { cutlery is placed onto the dish and into the bowls. The } \\
\text { transport continues to the table in the dining room. }\end{array}$ \\
\hline 3 & Serving & $\begin{array}{l}\text { The waiter places the } \\
\text { plate of food onto the } \\
\text { table in front of the } \\
\text { guest. }\end{array}$ & $\begin{array}{l}\text { The waiter places the bowls of potatoes and sauce } \\
\text { onto the table on the right side of the guest. } \\
\text { The waiter offers the fish dish on the left side of the } \\
\text { guest. } \\
\text { The guest serves herself fish from the dish. } \\
\text { The waiter leaves the guest and the table and trans- } \\
\text { ports the empty fish dish to the serving station or to } \\
\text { the kitchen. } \\
\text { The guest takes the bowl of potatoes and serves her- } \\
\text { self. She then puts the bowl back onto the table, on her } \\
\text { left side. } \\
\text { The guest takes the sauce bowl and serves herself } \\
\text { sauce. She then puts the sauce bowl back on the table, } \\
\text { on her left side. }\end{array}$ \\
\hline 4 & Completion & $\begin{array}{l}\text { The serving moment is } \\
\text { completed; the guest } \\
\text { now has a plate with } \\
\text { food on the table in front } \\
\text { of her. }\end{array}$ & $\begin{array}{l}\text { The serving moment is completed when the guest has } \\
\text { a plate with fish, potatoes, and sauce on the table in } \\
\text { front of her. The empty bowls are picked up by the } \\
\text { waiter and transported away from the table. }\end{array}$ \\
\hline
\end{tabular}


The use of the time-geographical concept - logs

The collected postulated data, based on the first author's own experiences, is compiled into two time-diaries, called: $\log$ for plate service and $\log$ for silver service. Each log has a chronological number and a name, and covers the procedures executed by three guests and one waiter. Descriptions are given both for the actions of the waiter and the guests. Based on the concept of constraints, different questions are listed and answered about any capacity, coupling, or authority constraints that may occur.

The use of the time-geographical concept - notation

TIME

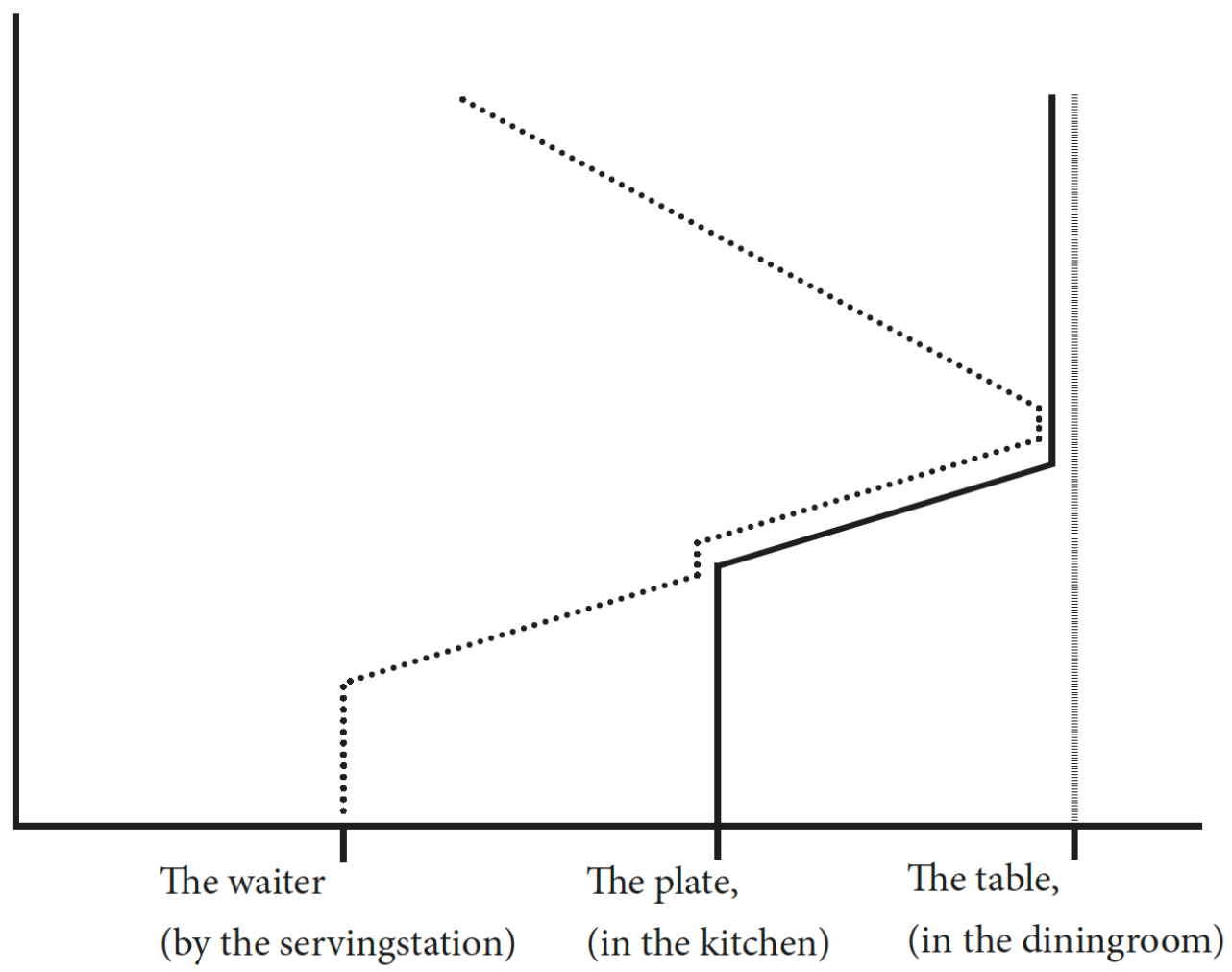

Figure 1. One human individual (a waiter) and two non-human individuals (a plate and a table) are included in this example. The waiter goes from the serving station to the kitchen and takes a plate of food (thereby, the waiter and the plate are joined together and form a bundle). The waiter and the plate arrive at the table (which is stationary) and now the three form a bundle (for a very short time). The waiter sets the plate down on the table and leaves. The waiter is now separated from both the table and the plate. A new bundle has emerged between the plate and the table.

A time-geographic notation will give additional information to the log both by visualizing and analysing activities in a project (Ellegård, 2019). The notation is a 
description that shows a sequence of activities performed by individuals, including movement activities, in the time-sequence and duration of activities (Ellegård, 2019). In the same way, a notation illustrates where and when someone (a human individual or a non-human individual) is in a defined project. The notation illustrates both beside-each-otherness and after-each-otherness and can be used to investigate how and why individuals, human and no-human, come together and leave each other (Ellegård, 2019) (Figure 1).

In order to understand silver service, which requires more procedures than plate service (see Table 1, row number 3), we have chosen to illustrate information from the $\log$ in a notation. Thereby, we will test whether the time-geographical concepts of being stationary, arriving, connecting, and separating can be used to provide explanations for the waiter's vocational knowledge.

In the end of next section, Results, a notation illustrates which individuals, (i.e., plate, platter, and waiter) are included in each procedure. When the trajectories for individuals, whether human or non-human, are combined in a serving procedure, they form a bundle. The notation visualizes when and where these different bundles occur and disappear. This method makes it possible to illustrate the length of time which different individuals take when participating in a serving procedure. The now-line shows the time at which the serving procedures are in progress.

\section{Results}

The investigation of the waiter's vocational knowledge inspired by time-geography results in two logs (one for each way of performing the project) and in one notation, which visualizes a vital part of the project using the silver service procedures. First, we compare the two logs before going deeper into the execution of the vocational knowledge by analysing the notation. Thereby, we bring to the fore the timing, duration, sequence, and specific location of the actions performed by the involved human individuals in the procedures and their use of non-human individuals. The notation also makes clear what is happening simultaneously. In summary, we suggest that the time-geographical concepts make visible the waiter's simultaneous capacity to understand, plan and execute procedures that take place in time and space. We will consider that the understanding of the waiter's craft procedures compares to Hägerstrand's (1982, p. 651) phrase 'a world on the move' but with a flexible and ongoing table landscape.

\section{Visualization of table-setting and serving procedures - logs}

When crafting procedures are noted in the log and questions are asked of the material based on the time-geographical concept of constraints, it is possible to point out the waiter's different types of knowledge which are necessary to carry out a serving procedure. By comparing the two different serving methods - plate 
service and silver service - we can make visible how something as seemingly simple as two serving methods means big differences in the knowledge required to carry out the task. These differences appear, for example, where and when socalled critical times occur in the serving order: in this case, the waiter setting the table she needs to choose cutlery which will prevent future coupling constraints between the characteristics of the dish and the shape of the cutlery (Table 2 and Table 3, Procedure 1).

Table 2. Postulated log for plate service.

\begin{tabular}{|c|c|c|c|c|}
\hline $\mathbf{N r}$ & Procedures & Waiter's actions & Guests' actions & Constraints \\
\hline 1 & $\begin{array}{l}\text { Table } \\
\text { setting }\end{array}$ & $\begin{array}{l}\text { The waiter pre- } \\
\text { pares the table } \\
\text { surface and sets } \\
\text { the knives and } \\
\text { forks. }\end{array}$ & None & $\begin{array}{l}\text { What knowledge does the waiter use } \\
\text { when preparing and choosing the most } \\
\text { suitable: } \\
\text { - Table area? } \\
\text { - Utensils (i.e., knife and fork)? } \\
\text { - Positions on the table for the utensils? }\end{array}$ \\
\hline 2 & $\begin{array}{l}\text { Sitting } \\
\text { down }\end{array}$ & $\begin{array}{l}\text { The waiter shows } \\
\text { the guests to the } \\
\text { table and hands it } \\
\text { over to the guests. }\end{array}$ & $\begin{array}{l}\text { The three guests } \\
\text { are seated at the } \\
\text { table. }\end{array}$ & $\begin{array}{l}\text { Can the table and utensils be interpreted } \\
\text { and used by the guests? }\end{array}$ \\
\hline 3 & $\begin{array}{l}\text { Waiting for } \\
\text { food }\end{array}$ & $\begin{array}{l}\text { The waiter is in } \\
\text { charge of the table } \\
\text { and the guests. }\end{array}$ & $\begin{array}{l}\text { The guests have } \\
\text { the opportunity } \\
\text { to act. }\end{array}$ & $\begin{array}{l}\text { Have the guests gained power over the } \\
\text { table area and utensils? How can they af- } \\
\text { fect them? For example, a guest might ac- } \\
\text { cidentally knock the cutlery onto the } \\
\text { floor. }\end{array}$ \\
\hline 4 & Plating & None & None & $\begin{array}{l}\text { The chef places food on the plates in the } \\
\text { kitchen. } \\
\text { Which plates does the chef choose? } \\
\text { Where and in what way is the food } \\
\text { placed on the plates? }\end{array}$ \\
\hline 5 & Leaving & $\begin{array}{l}\text { The waiter walks } \\
\text { away from the ta- } \\
\text { ble and the dining } \\
\text { room. }\end{array}$ & None & $\begin{array}{l}\text { What may occur once the waiter has lost } \\
\text { the control of the table and the guests? } \\
\text { For example, a guest may put her bag or } \\
\text { her laptop on the table? }\end{array}$ \\
\hline 6 & Transport & $\begin{array}{l}\text { The waiter picks } \\
\text { up the three plates } \\
\text { in the kitchen. The } \\
\text { food is trans- } \\
\text { ported from the } \\
\text { kitchen to the din- } \\
\text { ing room and then } \\
\text { to the table. }\end{array}$ & None & $\begin{array}{l}\text { Does the waiter have the ability to carry } \\
\text { the plates? } \\
\text { What are the size and the weight of the } \\
\text { plates, and how is the food positioned on } \\
\text { the plate? } \\
\text { Are the plates too big or too heavy? Is the } \\
\text { food positioned in a way that causes } \\
\text { risks to arise during the food's transpor- } \\
\text { tation? }\end{array}$ \\
\hline 7 & Serving & $\begin{array}{l}\text { The waiter places } \\
\text { one plate on the } \\
\text { table in front of } \\
\text { every guest. }\end{array}$ & None & $\begin{array}{l}\text { Are the guests ready at the time when } \\
\text { the food is served? Is the table surface } \\
\text { free of other items, such as bags and lap- } \\
\text { tops? } \\
\text { Are all the guests present at the table } \\
\text { (e.g., has anyone gone to the toilet)? }\end{array}$ \\
\hline 8 & Completion & $\begin{array}{l}\text { The waiter leaves } \\
\text { the table. }\end{array}$ & $\begin{array}{l}\text { The guests start } \\
\text { to eat. }\end{array}$ & $\begin{array}{l}\text { Until when does the waiter's control over } \\
\text { the table and guest continue? }\end{array}$ \\
\hline
\end{tabular}


Setting a table also involves deciding where to place the knife and fork. If the placement of the cutlery does not match the guests' expected standards for a table setting (Table 2, Procedure 1), authority constraints occur, which can be seen as an example of the waiter's craft, which includes understanding the guests' expectations.

In plate service, the waiter carries out the procedure of setting the table with all of the utensils, but not the plate (Table 2, Procedure 1). The waiter chooses the table and capacity constraints will occur if the table size is not large enough for the plate which will arrive to the table later (Table 2, Procedure 7). The chef might choose three plates that are not too big or too heavy, or that otherwise do not align with the waiter's plan to transport three plates at once (Table 2, Procedure 6). Though no coupling constraints should occur, it is included within the waiter's craft to communicate with the chef about the setting as well the transportation of the plates.

In silver service the table is set with all utensils, including the plates (Table 3, Procedure 1). The chef, in the kitchen, is involved in the service when he or she places fish, potatoes, and sauce in platters and bowls (Table 3, Procedure 4). To avoid capacity constraints for the waiter, the chef needs knowledge regarding the size, shape, and weight of the selected platters and bowls, so that they conform to the waiter's capacity to transport them. The placement of the food on the platter and in bowls can also contribute to coupling constraints should the waiter be unable to physically lift and transport these utensils (Table 3, Procedure 6).

In silver service, the serving procedures begin when the waiter places the bowls of potatoes and sauce onto the table. In order to avoid coupling constraints between the individuals, the bowls must be placed at a distance that allows the guest to reach them (Table 3, Procedure 9). The serving procedures continue when the waiter offers the platter of fish. The guest takes the serving cutlery and moves the fish onto her plate (Table 3, Procedure 10). If the guest takes too much fish, a capacity constraint will occur, since there will not be enough fish for the other guests sitting at the table. Authority constraints are imposed if the guest does not return the serving cutlery to the waiter or if the guest's actions take too long (Table 3, Procedure 10). To prevent capacity, coupling, or authority constraints from occurring, the guest needs to understand how many potatoes and how much sauce she can take; she also needs to understand how to move the bowls of potatoes and sauce so that the second guest can reach them. Here, it may be a standard or a norm that the guests understand that sharing a meal means to share the served food as well to share the served utensils. During silver service, many different constraints can arise. There are several critical points here, which are dependent on a number of procedures being risky when serving responsibilities are shared between guests. 
Lars Eriksson, Inger M. Jonsson \& Åsa Öström

Table 3. Postulated log for silver service.

\begin{tabular}{|c|c|c|c|c|}
\hline $\mathrm{Nr}$ & Procedures & Waiter's actions & Guest's actions & Constraints \\
\hline 1 & $\begin{array}{l}\text { Table } \\
\text { setting }\end{array}$ & $\begin{array}{l}\text { The waiter } \\
\text { prepares the } \\
\text { table surface } \\
\text { and sets the } \\
\text { plates, knives, } \\
\text { and forks. }\end{array}$ & None & $\begin{array}{l}\text { What knowledge does the waiter use } \\
\text { when preparing and choosing the most } \\
\text { suitable: } \\
\text { - Table area? } \\
\text { - Utensils (i.e., plate, knife, and fork)? } \\
\text { - Positions on the table for the utensils? }\end{array}$ \\
\hline 2 & $\begin{array}{l}\text { Sitting } \\
\text { down }\end{array}$ & $\begin{array}{l}\text { The waiter } \\
\text { shows the } \\
\text { guests to the } \\
\text { table. }\end{array}$ & $\begin{array}{l}\text { The guests are } \\
\text { seated at the ta- } \\
\text { ble. }\end{array}$ & $\begin{array}{l}\text { Can the table and utensils be interpreted } \\
\text { and used by the guests? }\end{array}$ \\
\hline 3 & $\begin{array}{l}\text { Waiting for } \\
\text { food }\end{array}$ & $\begin{array}{l}\text { The waiter is in } \\
\text { charge of the ta- } \\
\text { ble and guests. }\end{array}$ & $\begin{array}{l}\text { The guests have } \\
\text { the opportunity } \\
\text { to act. }\end{array}$ & $\begin{array}{l}\text { Have the guests gained power over the } \\
\text { table area and utensils? How can they af- } \\
\text { fect the table area? For example, a guest } \\
\text { might accidentally knock the cutlery onto } \\
\text { the floor. }\end{array}$ \\
\hline 4 & Plating & None & None & $\begin{array}{l}\text { Which platter and bowls are chosen by the } \\
\text { chef? How (in what form) is the food } \\
\text { placed in the bowls and onto the platter? }\end{array}$ \\
\hline 5 & Leaving & $\begin{array}{l}\text { The waiter } \\
\text { walks away } \\
\text { from the table. }\end{array}$ & None & $\begin{array}{l}\text { What may occur once the waiter has lost } \\
\text { control of the table and the guests? For } \\
\text { example, a guest may put her bag or her } \\
\text { laptop onto the table. }\end{array}$ \\
\hline 6 & Transport & $\begin{array}{l}\text { The waiter lifts } \\
\text { and transports } \\
\text { the fish dish and } \\
\text { the bowls of po- } \\
\text { tatoes and } \\
\text { sauce. }\end{array}$ & None & $\begin{array}{l}\text { Can the waiter carry the platter and the } \\
\text { bowls in one instance of transport? What } \\
\text { are the size and the weight of the dishes? } \\
\text { How is the food positioned on the platter } \\
\text { and in the bowls? Do any risks arise dur- } \\
\text { ing the transport? }\end{array}$ \\
\hline 7 & $\begin{array}{l}\text { Adding } \\
\text { serving } \\
\text { cutlery }\end{array}$ & $\begin{array}{l}\text { The waiter } \\
\text { places a serving } \\
\text { spoon and } \\
\text { serving fork on } \\
\text { the fish dish, a } \\
\text { potato spoon in } \\
\text { the potato bowl, } \\
\text { and a sauce } \\
\text { spoon in the } \\
\text { sauce bowl. }\end{array}$ & None & $\begin{array}{l}\text { Which serving cutlery does the waiter } \\
\text { choose? }\end{array}$ \\
\hline 8 & Transport & $\begin{array}{l}\text { The waiter goes } \\
\text { to the first guest. }\end{array}$ & None & $\begin{array}{l}\text { Can the waiter carry one dish and two } \\
\text { bowls, with the food and the added serv- } \\
\text { ing cutlery, in one instance of transport? }\end{array}$ \\
\hline 9 & Serving & $\begin{array}{l}\text { The waiter puts } \\
\text { the bowls of } \\
\text { potatoes and } \\
\text { sauce onto the } \\
\text { table. }\end{array}$ & None & $\begin{array}{l}\text { Does the waiter know where the sauce } \\
\text { bowl and the potato bowl should be } \\
\text { placed on the table? } \\
\text { Is there enough space on the table for the } \\
\text { bowls? }\end{array}$ \\
\hline 10 & Serving & $\begin{array}{l}\text { The waiter } \\
\text { offers the fish } \\
\text { dish to the first } \\
\text { guest. }\end{array}$ & $\begin{array}{l}\text { The first guest } \\
\text { takes the } \\
\text { serving spoon } \\
\text { and serving fork } \\
\text { and lifts a fish } \\
\text { fillet to her own } \\
\text { plate. }\end{array}$ & $\begin{array}{l}\text { Can the first guest use the serving cutlery } \\
\text { to serve herself the fish? For how long will } \\
\text { this guest use the serving cutlery? How } \\
\text { much fish will this guest take? }\end{array}$ \\
\hline
\end{tabular}


Waiters' craft-related actions studied from the perspective of time-geography

\begin{tabular}{|c|c|c|c|c|}
\hline 11 & Serving & $\begin{array}{l}\text { The waiter } \\
\text { finishes serving } \\
\text { the first guest } \\
\text { and moves on to } \\
\text { serve the second } \\
\text { guest. }\end{array}$ & None & $\begin{array}{l}\text { Can the second guest use the serving } \\
\text { cutlery to serve herself the fish? For how } \\
\text { long will this guest use the serving } \\
\text { cutlery? How much fish will this guest } \\
\text { take? }\end{array}$ \\
\hline 12 & Serving & & $\begin{array}{l}\text { The first guest } \\
\text { takes the potato } \\
\text { bowl, moves it } \\
\text { near to her } \\
\text { plate, takes the } \\
\text { serving spoon } \\
\text { and places } \\
\text { potatoes onto } \\
\text { her plate. Next, } \\
\text { the guest moves } \\
\text { the potato bowl } \\
\text { over to the } \\
\text { second guest. }\end{array}$ & $\begin{array}{l}\text { Does the first guest know that she should } \\
\text { move the potato bowl closer to her own } \\
\text { plate? How many potatoes will this guest } \\
\text { take? Does the guest know that she should } \\
\text { then move the potato bowl away from her } \\
\text { own plate and closer to the second guest? }\end{array}$ \\
\hline 13 & Serving & & $\begin{array}{l}\text { The first guest } \\
\text { takes the sauce } \\
\text { bowl, moves it } \\
\text { near to her } \\
\text { plate, takes the } \\
\text { serving spoon, } \\
\text { and places the } \\
\text { sauce onto her } \\
\text { plate. Next, the } \\
\text { guest moves the } \\
\text { sauce bowl over } \\
\text { to the second } \\
\text { guest. }\end{array}$ & $\begin{array}{l}\text { Does the first guest know that she should } \\
\text { move the sauce bowl closer to her own } \\
\text { plate? How much sauce will this guest } \\
\text { take? Does the guest know that she should } \\
\text { then move the sauce bowl away from her } \\
\text { own plate and closer to the second guest? }\end{array}$ \\
\hline 14 & Transport & $\begin{array}{l}\text { The waiter } \\
\text { leaves the table } \\
\text { and goes away } \\
\text { with the empty } \\
\text { fish dish. }\end{array}$ & $\begin{array}{l}\text { The guests' self- } \\
\text { service of pota- } \\
\text { toes and sauce } \\
\text { continues after } \\
\text { the waiter leaves } \\
\text { the dining room. }\end{array}$ & $\begin{array}{l}\text { What can happen when the waiter loses } \\
\text { control of the table and the guests? } \\
\text { What can happen as the guests serve } \\
\text { themselves with potatoes and sauce? }\end{array}$ \\
\hline 15 & Arrival & $\begin{array}{l}\text { The waiter } \\
\text { returns to the } \\
\text { table. }\end{array}$ & None & $\begin{array}{l}\text { Are the guests finished serving themselves } \\
\text { potatoes and sauce? }\end{array}$ \\
\hline 16 & $\begin{array}{l}\text { Transport } \\
\text { and } \\
\text { completion }\end{array}$ & $\begin{array}{l}\text { The waiter picks } \\
\text { up the bowls } \\
\text { and takes them } \\
\text { away from the } \\
\text { table. }\end{array}$ & $\begin{array}{l}\text { The guests start } \\
\text { to eat. }\end{array}$ & $\begin{array}{l}\text { What can happen when the waiter loses } \\
\text { the control of the table and the guests? }\end{array}$ \\
\hline 17 & Completion & $\begin{array}{l}\text { The waiter } \\
\text { leaves the table. }\end{array}$ & None & $\begin{array}{l}\text { Until when does the waiter's control over } \\
\text { the table and guests continue? }\end{array}$ \\
\hline
\end{tabular}

\section{Visualization of serving in time and space - notation}

To make visible that the craft procedures in silver service are much more complex than in plate service due to the fact that the serving is shared between waiter and guest, as well as between guest and guest, a notation is made (Figure 2). The information from the silver service log which describes in text what happens, when 
it happens, for how long is goes on and who participates has been transferred to a notation. This gives the opportunity to replicate sequences of the waiter's and guests' complex activities.

The notation thus provides, for example, a visual image that shows that the waiter is able to ensure that material resources are in the right place and at the right time which can be described by the time-geographical concept of side-byside-ness. The notation also provides the opportunity to visualize how activities occur in time, explained by the time-geographical concept of before-and-afterness. By noting the time on the y-axis, it becomes possible to illustrate the waiter's order of different serving procedures; by noting location indications on the $\mathrm{x}$ axis, it is possible to see all the different places that the waiter uses in his work. The notation makes it easy to see the interplay in the time-space between the different kinds of individuals (human individuals and non-human individuals) during the procedures as well as when a procedure is completed. To illustrate the notation in a more communicative way, we have added an illustration at the bottom of the notation.

The notation (Figure 2) indicates that at the 1-minute point, three activity bundles are formed of the various individuals as follows:

- The waiter, the fish dish, the fish spoon and the fish fork form a blue activity bundle;

- The potato bowl and the spoon form a red activity bundle; and

- The sauce bowl and the sauce spoon form a green activity bundle.

At the time when the waiter invites guest A to take a portion of fish (at the 1.5minute point), guest $\mathrm{A}$ becomes connected with the waiter's blue activity bundle. When guest A is ready for this activity, she is separated from the blue activity bundle. Soon after, guest A connects to the red bundle for the purpose of serving herself potatoes and after a while she is separated from this bundle. Thereafter, she is connected and separated to the green bundle to serve herself sauce. This happens at the same time as the waiter invites guest B to take fish. The waiter has a physical connection to the blue trajectory during the whole serving procedure. But at the same time the waiter shares the physical responsibility of the fish spoon and fish fork with the guests because the waiter offers the cutlery to them when they have to transfer the fish onto their own plates. This is visible in the blue bundles (Figure 2). 


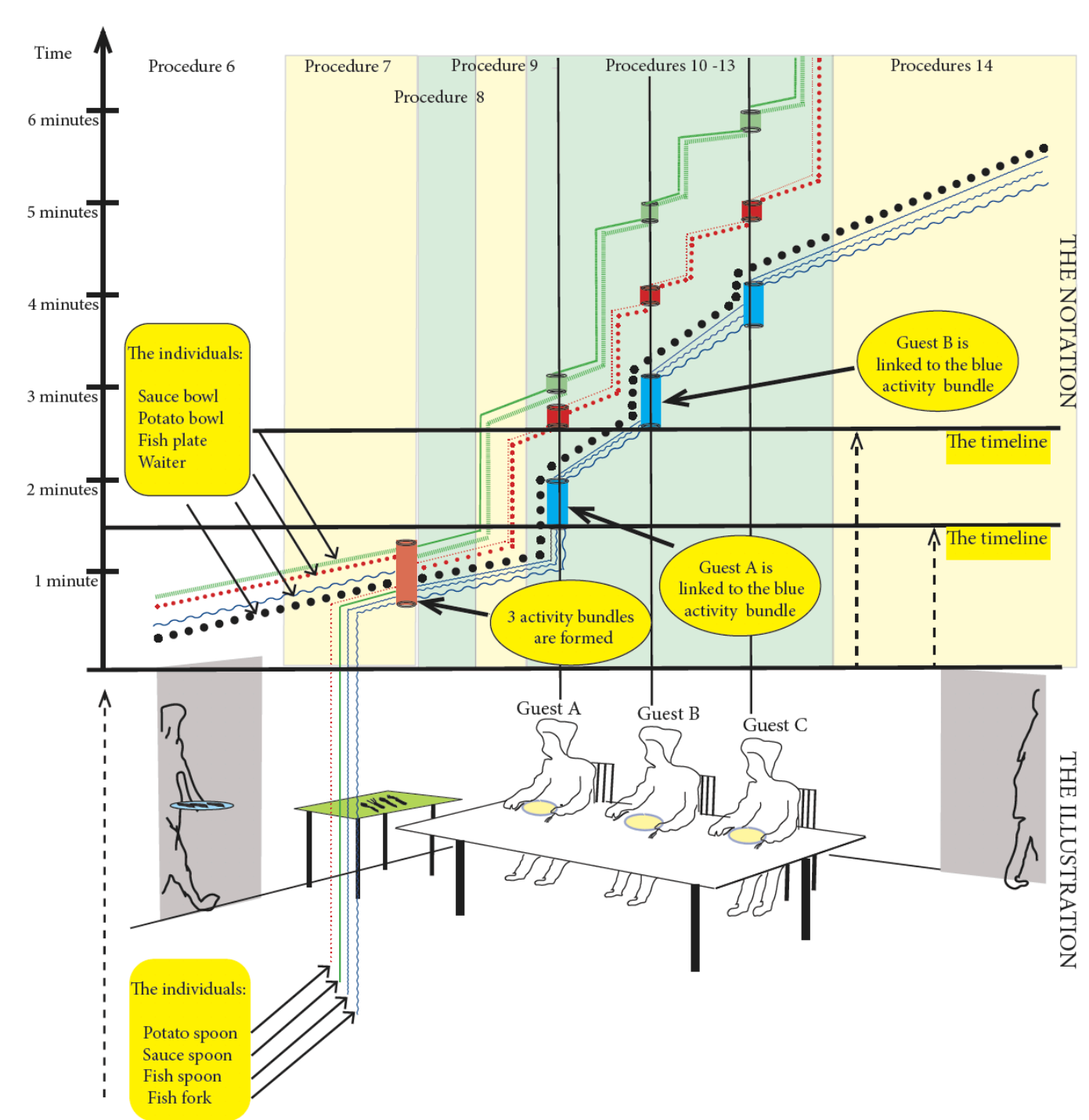

Figure 2. The illustration, Visualization of silver service in time and space, is a development of the illustration The Child and the Butterfly (Hägerstrand, 2009, p. 116).

The significance of the waiter's understanding of the after-each-otherness becomes visible as the notation system shows that procedures must be performed in a certain order. At the same time, following the timeline reveals that some procedures take place in parallel during the serving process; for example, while the waiter invites guest B to serve herself fish, guest A is serving herself sauce. Thus, the waiter's understanding of after-each-otherness and beside-each-otherness is part of the knowledge that the waiter has when performing a dining situation. Hereby, through the notation, it is possible to visualize and communicate complex serving procedures that occur simultaneously and in a timely manner. 


\section{Discussion}

The aim of this article is to visualize, communicate, and understand the vocational knowledge of a waiter's craft, including the actions of table-setting and serving. This study shows that time-geographical key concepts such as time, space, and individuals are transferable to the context of Culinary Arts and Meals Science. The waiter's work is characterised by different path choices, where the decisions made before each situation are characterised by the relationship between time, space, and its various individuals consisting of people and things. These three aspects affect every table-setting and serving situation, which are performed every day, everywhere. In order to understand the waiter's vocational knowledge and to be able to convey its content to the situations of teaching and training, but also in the professional world, the craftsmanship needs to be conceptualised. The time-geographical approach with its concepts is one way of approaching knowledge that is sometimes referred to as 'tacit knowledge'.

In the next section we will discuss the methods and approaches of timegeography and how these have enabled us to get closer to descriptions of the waiter's vocational craft knowledge.

\section{Discussion of the method}

Through the use of the time-geographical methods, we investigate the approach used by Dunin-Woyseth and Nilsson (2017) and Sjömar (2017), wherein the focus of craft knowledge is shifted from a practical production field to an exploratory research field, to answer questions about how a craft procedure is carried out. We believe that this is important to achieve development in our research field.

With support both from the field of crafts (Almevik, 2011; Ehn, 2014) and from the field of time-geography (Ellegård, 2019), we have broken down some serving procedures into smaller parts. The time-geographical perspective makes it possible to pay attention to the many different choices and decisions that the craftsman needs to make in each crafting procedure. This allows us to understand the complexity of dining procedures. We have sorted the data from two well-known serving methods - plate serving and silver service - into time-geographical logs.

In this study, we have not been interested in identifying what is right or wrong in a traditional way of serving. Those answers would be dependent on the dining context (Gustafsson, 2004). Instead we have chosen to remove the experiencebased part of the craft, in order to get deeper into an understanding of what the practical benefits of the waiter's procedures are. We believe that this abstraction makes it possible both to talk about and to teach and train in the profession of the waiter in a more intellectual, and at the same time technical way. This means that in a teaching occasion the practical part of the craft (like the function of moving material) cannot be hidden through the social interaction between waiter and guest, discussed by Walter (2011). In the same way, time-geography has no 
primary ambitions to discuss experiences or meaning of projects (Åquist, 1992). By using the concept of constraints, it is possible to visualize underlying aspects of a waiter's knowing that are necessary to perform a serving procedure. Seeking out, by questions, what could be a constraint allows for determining the factors which enable a project to be successfully carried out. This methodological approach, to ask what is an obstacle, makes it possible to describe possibilities and limits of projects (Hägerstrand, 1970). Searching for constraints in this way provides an opportunity to explain (Åquist, 1992) what seems obvious in a waiter's craft procedure. The time-geography approach breaks down the data of the time, space, and individuals to a very basic and ordinary level (Hägerstrand, 2009). When we elucidated what the various table-setting and serving procedures are and what actions the waiter performs, we perceive knowledge pertaining to a level that Rolf (2017) defines as abilities on a fundamental level.

The notation with its graphics shows that a crafting process is ongoing in a flow of individuals who move around in time and space (Gustafsson, 2004; Gustafsson et al., 2006; Walter, 2011; Åquist, 1992). Through the notation, together with the illustration of a table with its guests and a waiter in a restaurant room, we show what the waiter has to manage. The notation shows when and where individuals, who are dependent upon one another, must be brought together and separated. Hereby, we make visible one part of the waiter's knowledge that Lundquist (2006) suggests is to carry out the transportation of utensils from one place to another. In the same way, by the time-geographical concepts and methods, we can visualize and communicate when and where different actors (human and non-human) integrate in a meal experience. From this, it will be possible to communicate when and where, in a meal experience, the social interactions between guests could be possible in the way Walter (2011) suggests. The notation together with the illustration describes and explains how the waiters affect this studied meal situation in aspects of space and time; this can be viewed in contrast to the log, which gives no spatial view. The log is a time-diary that notes the event and time, while the notation illustrates the event and its duration in time, and location in the room wherein the procedure takes place. Through the use of both the $\log$ and the notation, this study has demonstrated the ability to visualize, communicate and understand, the waiter's craft-related actions. The time-geographical method can also feel foreign; for example, when it touches on what is so close to the waiter's everyday reality, the approach can be perceived as stating the obvious. Hägerstrand (2009) believes, however, that we also need to see the obvious to manage a resource utilisation in a joint existence. One difficulty in this study has been to limit the data, since the view of time-geography means to see the world as a myriad of threads where everything is linked together as in a weave. When everything according to time-geography belongs in huge systems of bonds, it becomes difficult to delineate. This combined with the first author's own long experience and understanding of the waiter's profession, which can 
also be likened to a weave of experience, has made it difficult to formulate and limit the data. At the same time, we believe that the method can clearly be seen as a bridge between Culinary Arts and Meal Science and Craft Science, thus enabling new approaches to study the waiter's vocational knowledge.

\section{Discussion of the result}

Concepts and methods from time-geography allow researchers to both separate and integrate factors, such as time, space, humans and non-humans (materials things), and to use separation/integration in order to look at them as constraints/facilitators when a project is performed. The flow of events takes place as after-each-otherness and is largely controlled and influenced by the waiter, who has mastered the materiality of the period. As a result, chains of events that affect each other can emerge from the hidden, the often unspoken and the toooften forgiven taken. The notation also makes visible parallel activities, besideeach-otherness, which are simultaneously going on in the time-space. A meal always takes place in some kind of spatiality and requires time to be implemented. Hereby, we will describe how the concept of time is compared to timing, how the concept of space is compared to table/dining room, and how the concept of individual is compared to waiters/guests/utensils.

\section{Time}

In time-geography, time is a basic dimension for all existence, and in our analysis, timing is a vital aspect of time. A waiter's vocational knowledge involves mastering chains of events that occur over a period of time. In the same way, the waiter needs to have an understanding that table-setting and serving need to be performed in a certain time frame. This part of the waiter's knowledge is usually taken for granted. Traditional knowledge transfer from master to apprentice means that instructions are given that serving should be done in the right time and in the right order (Wellton, 2017). The notation (Figure 2) highlights the often unspoken professional practice. Through the notation it is possible to demonstrate at what time, in which before-and-afterness (Ellegård, 2019; Hägerstrand, 2009) the waiter needs to make a decision (Gustafsson, 2004; Gustafsson et al., 2006)

\section{Room}

In this study, the time-geographical concept space equated is the room. In Culinary Arts and Meal Science the FAMM model is a central framework and the room is one part (Gustafsson et al., 2006). In discussions about the room in perspective of FAMM as well as the room as concepts of 'service-scape' and 'experience room' (Bitner, 1992; Walter, 2011) the importance of the room and the tablesetting for a guest experience (Gustafsson, 2004), are common. Difficulties arise when room for ongoing procedures are to be explained. Hägerstrand suggests 
that we need to see the space, or room, in terms of 'a world on the move' (1982, p. 651). Similarly, in this article, we try to examine the restaurant's room based on the idea of a changing space - that is, a room which is influenced by its individuals. Models that can describe a changing space are one step towards making visible the waiter's vocational knowledge. Models that capture flows with events can complement knowledge as 'knowing that' (Ryle, 1949). 'Knowing that' points out, for example, where utensils must be placed on the table surface or where the table should be placed in the room (Hedman, 1999). However, 'knowing how' means to understand how materials that are moved in the room, both by guests and by staff, affect the waiter's craft procedures. The time-geographic approach makes it possible both to visualize and communicate this flow of material movements, which are a large part of the waiter's vocational knowledge. The dining room is not a stationary room but a room that is constantly changing.

\section{Individuals}

Through the time-geographic notation it is possible to discern which individuals are onsite within a given craft procedure. We demonstrate that a skilled waiter needs to possess knowledge about which serving procedures are onsite and which individuals are dependent upon or independent from one another in a serving procedure. To make the notation at more synoptic level, we created an illustration in the lower part of the notation. It illustrates the different individuals of the notation as well as the stations at which they are located at the beginning of the serving. The illustration makes it easier to visualize how the trajectories of the individuals (i.e., people and materials) are moving between different stations in the time-space.

\section{Craft}

How rooms are affected by presence of different individuals (human and nonhuman) is something which is rarely emphasised in educational materials. The same can be said for how rooms are affected by the time at which an individual (human and non-human) arrives at or leaves the room. This is usually something that 'just happens' through the crafting procedures. With the support of the timegeography, it is possible to shed light on how the time, the room, and the individuals are linked together by different serving procedures. When a map, or a notation, shows the geographical location of places, the content of the waiter's vocational knowledge can be described. The definition of the waiter's level of craftsmanship becomes apparent when she makes decisions that alter the tablesetting and the serving craft procedures. This definition of craft is supported by the reasoning of Tempte (1982), who believes that craft is a question of different and difficult decisions that the craftsman is compelled to make. We believe that time-geography can highlight the complexity of craft procedures in terms of the many different choices a craft person is faced with and the many different 
decisions they must make and act on. Many of these decisions are made at a rapid pace by the professional. The seemingly simple crafting procedures appear here as a result of the reflective practitioner. The level of vocational knowledge can become visible through the concepts of constraints, which demonstrate how everything that occurs occupies both time and space. At the same time, reflective decisions can help to explain how, when, and where the waiter's decisions affect the results of table-setting and serving procedures.

The results from the log (Table 3) show that silver service generates more procedures than plate service. In the same way, more questions are posed for silver service based on the concept of constraints, and thereby it becomes apparent that silver service involves more risks than plate service. This finding is consistent with Pye's (1968) definition of craft, which states that craft involves elements of risk taking. Using time-geography, we show here that the silver service becomes more salient, partly because the serving procedures are shared between the guests and the waiter. We are suggesting that silver service can be referred to, in the words of Pye (1968), as a 'workmanship of risk'. On the other hand, plate service can be compared to a task that is performed on the basis of security, giving it more of a predetermined nature, and can be referred to as a 'workmanship of certainty' (Pye, 1968). Therefore, we suggest that silver service can be categorised as more of a craft procedure than plate service.

\section{Conclusion}

By studying the waiter's craft from a time-geographical perspective, and comparing plate serving with silver service in two logs, we have come to understand the waiter's different levels of knowledge for table-setting and serving. The logs, together with the notation, clarify three categories of knowledge as time, space, and individual, which together communicate parts of the waiter's vocational knowledge. When the waiter, in words and through illustrations, describes choices and decisions for her craft procedures, it is possible to visualize, communicate, and understand, how she masters and predicts time, materiality, and spatiality. Such a theoretical approach intellectualises the waiter's crafting procedures, which is important in educational situations. Furthermore, in the professional world, too, it becomes possible to demonstrate that the waiter has a great understanding of time, space, and materiality and how these elements interact. This makes it possible to give the vocational role of a waiter a higher status.

\section{Notes on contributors}

Lars Eriksson is a PhD student in Culinary Arts and Meal Science, Campus Grythyttan, Örebro university. His research interest focus on methods to document, visualize and communicate craft knowledge in the restaurant area 
according to table setting and serving. His interest is to increase the knowledge, which is often unarticulated and difficult to convey, for further use in research educational areas as well as in professional practice.

Inger M. Jonsson is $\mathrm{PhD}$ and professor in Culinary Arts and Meal Science, Campus Grythyttan, Örebro university. Her research field is meals and meal experience in a societal perspective, particularly 'meals for many' in restaurant and public sectors, meals at different parts of life and the importance of gender and ethnicity for the view of food. She is also interested in how a university subject with practical and aesthetic methods can be anchored in scientific theory.

Åsa Öström is $\mathrm{PhD}$ and professor in Culinary Arts and Meal Science, Campus Grythyttan, Örebro university. Her field of research include sensory research from an interdisciplinary perspective such as basic research in complex meal and multisensory settings. Current research focuses on developing methods in sensory science that assess food combinations and how sensory experiences can be communicated. 


\section{References}

Almevik, G. (2011). Professor i byggnadsarbete? [Professor of construcition work?]. In G. Almevik, L. Bergström, \& E. Löfgren (Eds.), Hantverkslaboratorium [Craft laboratory] (pp. 38-48). Mariestad: Hantverkslaboratoriet, Göteborgs universitet.

Almevik, G. (2014). Hantverkare emellan: Perspektiv på hantverkens kunskapskultur [From one craftsman to another: Perspectives on knowledge culture in crafts]. In G. Almevik, S. Höglund, \& A. Winbladh (Eds.), Hantverkare emellan [From one craftsman to another] (pp. 7-12). Mariestad: Hantverkslaboratoriet, Göteborgs universitet.

Almevik, G. (2017). Hantverkligt vetenskapande [Making craft research]. In G. Almevik (Ed.), Hantverksvetenskap [Craft science] (pp. 7-12). Mariestad: Hantverkslaboratoriet, Göteborgs universitet.

Alvesson, M., \& Sköldberg, K. (2008). Tolkning och reflektion: Vetenskapsfilosofi och kvalitativ metod [Interpretation and reflection: Philosophy of science and qualitative methods]. Lund: Studentlitteratur.

Åquist, A-C. (1992). Tidsgeografi i samspel med samhällsteori [An interplay between time-geography and social theory]. (Doctoral thesis). Lund: Lund University Press.

Bitner, M.J. (1992). Servicescapes: The impact of physical surroundings on customers and employees. Journal of Marketing, 56, 57-71.

Billing, M., \& Wahlström, Å. (2004). Samtal mellan Birgitta Ulmander och två sommelierer [Conversations between Birgitta Ulmander and two sommeliers]. In I-B. Gustafsson, \& U-B. Strömberg (Eds.), Tid för Måltidskunskap [Time for Culinary Arts and Meal Science] (pp. 55-65). Örebro: Örebro universitet, Måltidskunskap, Culinary Arts and Meal Science 1.

Culinary Institute of America. (2001). Remarkable service: A guide to winning and keeping customers for servers, managers, and restaurant owners. New York: Wiley.

Dreyfus, H., \& Dreyfus, S. (1988). Mind over machine: The power of human intuition and expertise in the era of the computer. New York: Free Press.

Dunin-Woyseth, H., \& Nilsson, F. (2017). Four arrows of knowledge: Some notes on practice-based research. In G. Almevik (Ed.), Hantverksvetenskap [Craft science] (pp. 39-45). Mariestad: Hantverkslaboratoriet, Göteborgs universitet.

Ehn, B. (2014). Komma åt detaljerna - Att intervjua, observera och skriva om traditionella hantverkskunskaper [Access the details - To interview, observe and write about traditional craftsmanship]. In G. Almevik, S. Höglund, \& A. Winbladh (Eds.), Hantverkare emellan [From one craftsman to another] (pp. 30-43). Mariestad: Hantverkslaboratoriet, Göteborgs universitet.

Ellegård, K. (2019). Thinking time geography: Concepts, methods and applications. New York: Routledge. 
Eriksson, L, Seiler, J., Jarefjäll, P., \& Almevik, G. (2019). The time-space of craftsmanship. Craft Research, 10(1), 17-39.

Gustafsson, I-B. (2004). Culinary arts and meal science: A new scientific research discipline. Food Service Technology, 4(1), 9-20.

Gustafsson, I-B., Öström, Å., Johansson, J., \& Mossberg, L. (2006). The five aspects meal model: A tool for developing meal services in restaurants. Journal of Food services 17, 84-93.

Hedman, U. (1999). Serveringskunskap [Knowledge of serving]. Stockholm: Gästakademien i samverkan med Sellin \& partner.

Hägerstrand, T. (1970). What about people in regional science? Regional Science Association Papers, XXIV, 7-21.

Hägerstrand, T. (1982). Diorama, path and project. Tijdschrift voor Economische en Sociale Geographie, 73(6), 632-639.

Hägerstrand, T. (2009). Tillvaroväven [The fabric of existence]. K. Ellegård, \& U. Svedin (Eds.). Stockholm: Formas.

Ingold, T. (2013). Making: Anthropology, archaeology, art and architecture. London: Routledge.

Jarefjäll, P. (2016). Navarsmide [Forging of the twisted auger]. (Licentiate thesis). Göteborg: Göteborgs universitet, Institutionen för kulturvård.

Jonsson, I.M., Nygren, T., \& Pipping Ekström, M. (2006). Mentorskap, mat- och vinkunskap, arbetskläder, yrkesbenämningar [Mentorship, food and wine knowledge, work clothes, professional terms]. In M. Pipping Ekström (Ed.), Genus på krogen [Genus at the restaurant] (pp. 7-34). Örebro: Örebro universitet, Måltidskunskap, Culinary Arts and Meal Science 2.

Lauvås, P, Handal, G., \& Nilsson, B. (2015). Handledning och praktisk yrkesteori [Guidance and practical professional theory]. Lund: Studentlitteratur.

Lenntorp, B. (2011). En inblick i den hägerstrandska vävens begreppsflora [An insight into the flora of the Hägerstrand weave]. In J. Palm, \& E. Wihlborg (Eds.), Sammanvävt: Det goda livet $i$ vardagsforskningen. En vänbok till Kajsa Ellegård [Woven together: The good life in everyday research. A friend's book to Kajsa Ellegård] (pp. 123-137). Linköping: Tema Teknik och Social Förändring, Linköpings universitet.

Lundqvist, H. (2006). Lågstatusjobb på högstatuskrogar [Low-status jobs at highstatus restaurants]. In M. Pipping Ekström (Ed.), Genus på krogen [Genus at the restaurant] (pp. 35-83). Örebro: Örebro universitet, Måltidskunskap, Culinary Arts and Meal Science 2.

Molander, B. (1996). Kunskap i handling [Knowledge in action]. Göteborg: Daidalos.

Mårtensson, S. (1979). On the formations of biographies in space-time environments. (Doctoral thesis). Lund: Lunds universitet.

Polanyi, M. (1958). Personal knowledge: Towards a post-critical philosophy. London: Routledge. 
Pye, D. (1968). The nature and art of workmanship. Cambridge: Cambridge University Press.

Rolf, B. (2017). Teori, praktik och kompetens [Theory, practice and competence]. In G. Almevik (Ed.), Hantverksvetenskap [Craft science] (pp. 49-80). Mariestad: Hantverkslaboratoriet, Göteborgs universitet.

Ryle, G. (1949). The concept of mind. London: Penguin Books.

Schön, D. (1983). The reflective practitioner: How professionals think in action. New York: Basic Boks.

Sjömar, P. (2011). Hantverkares kunskap [Craftsman knowledge]. In G. Almevik, L. Bergström, \& E. Löfgren (Eds.), Hantverkslaboratorium [Craft laboratory] (pp. 62-86). Mariestad: Hantverkslaboratoriet, Göteborgs universitet.

Sjömar, P. (2017). Hantverksvetenskap, Rapport från försök med hantverksinriktad forskarutbildning, del 1 [Experimental work with doctorial studies on the science of craftsmanship, part 1]. In G. Almevik (Ed.), Hantverksvetenskap [Craft science] (pp. 83-166). Mariestad: Hantverkslaboratoriet, Göteborgs universitet.

Statens offentliga utredningar. (2017). SOU 2017:95 Ett land att besöka: En samlad politik för hällbar turism och växande besöksnäring [A country to visit: A unified policy for sustainable tourism and the growing tourism industry]. Betänkande av Utredningen Sveriges besöksnäring. Stockholm: Statens offentliga utredningar.

Tempte, T. (1982). Arbetets ära: Om hantverk, arbete, några rekonstruerade verktyg och maskiner [Work honor: About crafts, work, some reconstructed tools and machines]. Stockholm: Arbetslivscentrum.

Walter, U. (2011). Drivers of customers' service experiences: A customer perspective on co-creation of restaurant services, focusing on interactions, processes and activities. (Doctoral thesis). Örebro: Örebro universitet.

Wellton, L. (2017). Making meals in restaurants: Daily practices and professional ideals. (Doctoral thesis). Örebro: Örebro universitet.

Westerlund, T. (2017). Trädgårdsmästarens förökningsmetoder: Schema och katalog över förökningsdelar vid vegetativ förökning av fleräriga örtartade växter [The gardener's propagation methods: Documentation of craft knowledge]. (Doctoral thesis). Göteborg: Göteborgs universitet, Institutionen för kulturvård. 